УДК 37.015.3:005.32:33

DOI:

Олена Ільєнко, кандидат філологічних наук, доцент кафедри іноземних мов Харківського національного університету міського господарства імені О.М. Бекетова

\title{
СТАТИСТИЧНА ОБРОБКА ТА АНАЛІЗ РЕЗУЛЬТАТІВ ЕКСПЕРИМЕНТАЛЬНОЇ РОБОТИ З ФОРМУВАННЯ КОНКУРЕНТОСПРОМОЖНОСТІ МАЙБУТНЬОГО ФАХІВЦЯ МУНІЦИПАЛЬНОЇ ЕКОНОМІКИ
}

У статті надано аналіз статистичної обробки результатів дослідно-експериментальної роботи з формування конкурентоспроможності майбутнього фахівия муніципальної економіки. Відзначається, щуо для визначення сформованості конкурентоспроможності майбутніх фахівиів муніципальної економіки було виявлено кількісні та якісні зміни компонентів зазначеного утворення у студентів ЕГта КГ через дослідження таких критеріїв як мотивація професійного навчання, мотивачія на успіх/невдачу, потреба у досягненнях, сформованість фахових компетенцій, сформованість іншомовної компетентності, здатність до адаптаиії, здатність до творчості, самостійність, вміння йти на ризик, комунікабельність та рефлексивність. Зроблено висновок про те, щэо результати експерименту є статистично значущими відповідно представлених обчислень за методами математичної статистики, щьо свідчить про ефективність розробленої науково-методичної системи.

Ключові слова: конкурентоспроможність фахівия; фахівець муніципальної економіки; критерії та показники конкурентоспроможності; формування конкурентоспроможності; науково-методична система; дослідно-експериментальна робота; статистична обробка.

Табл. 5. Рис. 1. Літ. 12.

Olena Ilyenko, Ph.D.(Philology), Associate Professor of the Foreign Languages Department Kharkiv Oleksiy Beketov National University of Urban Economy

\section{STATISTICAL PROCESSING AND ANALYSIS OFTHE RESULTS OF EXPERIMENTAL WORK ON FORMING COMPETITIVENESS OF FUTURE PROFESSIONALS OF MUNICIPAL ECONOMY}

The article focuses on statistical processing and analysis of the results of the experimental work on forming competitiveness of the future professional of municipal economy. A review of the scientific literature on the issues of training various components of competitiveness of the future professional is presented.

The author informs that in order to test the hypothesis about the effectiveness of the scientific system for forming the competitiveness of future professionals of municipal economy it was necessary to identify the quantitative and qualitative changes in the components of this phenomenon for the students of the experimental and control groups using the suggested criteria, namely, motivation for success / failure, the need for achievements, professional competences, foreign language competence, adaptability, creativity, autonomy, risk-taking, social skills and reflexivity. The characteristics for each of the levels of competitiveness formation, namely, high, medium and low, are determined.

Information is provided that in order to confirm the reliability of the results of the experiment, the methods of mathematical statistics were used. In particular, a statistical analysis of the integrated data of the experiment were analyzed using descriptive statistics, namely, the arithmetic mean, the sample variance and the sample standard deviation of the levels of competitiveness formation for future professionals of municipal economy.

It is mentioned that testing the hypothesis on increasing the levels of generalized indices in the experimental group was made using the Student's criterion but in order to confirm the significance of the statistical conclusions, the Fisher's criterion was applied.

Summarizing the overall results of the experimental work and the statistical processing, the author concludes that the results obtained show a significant positive change in dynamics of all the criteria of competitiveness formation, indicating the effectiveness of the experimentally tested scientific system. The results of the experiment are statistically significant according to the presented calculations made using the methods of mathematical statistics.

Keywords: competitiveness of the professional; professional of the municipal economy; competitiveness criteria and indicators; competitiveness forming; scientific and methodic system; research and experimental work; statistical processing.

П

остановка проблеми. Формування конкурентоспроможності майбутнього фахівця визначається одним 3 актуальних завдань сучасної професійної підготовки в закладі вищої освіти. Важливою для сучасного фахівця стає здатність забезпечити собі стійке положення на ринку праці, готовність до діяльності в умовах конкурентної боротьби, 


\section{СТАТИСТИЧНАОБРОБКА ТААНАЛІЗ РЕЗУЛЬТАТІВ ЕКСПЕРИМЕНТАЛЬНОӤ РОБОТИЗФОРМУВАННЯ КОНКУРЕНТОСПРОМОЖНОСТІМАЙБУТНЬОГОФАХІВЦЯМУНШИПАЛЬНОӤЕКОНОМІКИ}

мобільності та безперервного професійного забезпечення викладання додаткової дисципліни, вдосконалення.

Оскільки конкурентоспроможність $є$ комплексним інтегративним утворенням, більшість дослідників наголошує на необхідності розробки та впровадження в навчальний процес науково-методичної системи формування конкурентоспроможності майбутнього фахівця певної галузі. Уважаємо, що формування конкурентоспроможного фахівця муніципальної економіки потребує розробки, впровадження та експериментальної перевірки науково-методичної системи, яка дозволяє позитивно впливати на розвиток потребово-мотиваційного, когнітивноопераційного та рефлексивно-оцінного компонентів конкурентоспроможності, а також комплексу критеріїв та показників цього феномена, шо відображають його сутнісні характеристики.

Метою статті $\epsilon$ представлення аналізу результатів експериментальної перевірки науковометодичної системиформування конкурентоспроможності майбугніх фахівців муніципальної економіки та методики їх статистичної обробки.

Аналіз останніх досліджень і публікацій. Різноманітніаспектиформуванняконкурентоспроможності майбугніх фахівців окремих галузей економіки та структурні елементи конкурентоспроможності розглядалась у працях ряду вітчизняних та зарубіжних науковців $[1 ; 2 ; 4 ; 7 ; 10]$.

В нашому дослідженні при розробці засобів формування когнітивно-операційнного компоненту майбутнього фахівця спирались на думку В. Бодрова щодо визначення основних характеристик професійного становлення фахівця загальної та професійної підготовленості, що виявляється у формі попередніх (для опанування професіі) і кваліфікаційних (з урахуванням рівня професіоналізації) знань та умінь, необхідних для виконання стандартних та нетипових професійних завдань [2]. Вважаємо таку авторську думку де в чому дотичною до теорії таксономії цілей Б. Блума, що дозволяє визначати рівень компетентності фахівця через вимірювання його діяльності на когнітивній, афективній та психомоторній сферах [12].

Цікавим підходом щодо формування будьякого утворення у студентів в процесі фахової підготовки вважаємо досвід О. Резван, у якому доведено доречність уведення елементів науковометодичного доробку з теми дослідження до різних дисциплін згідно планупідготовки фахівця. Зокрема, автор стверджує, що за умови організації експерименту у такому вигляді, по-перше, зникає проблема корекції навчального плану, ресурсного а по-друге, експеримент реалізовується у межах корекції змісту декількох дисциплін, а отже, проблема дослідження актуалізується у різних галузях наукового знання [9, 321]. Отже, підкреслюючи важливість реалізації принципу наступності та перспективності у фаховій підготовці загалом та у формуванні конкурентоспроможності зокрема, наголошуємо на необхідності виокремлення навчальних дисциплін на різних курсах та корекцію їх змісту iз акцентом на окремих аспектах проблеми конкурентоспроможності фахівця муніципальної економіки.

Зауважуючи на важливості у формуванні конкурентоспроможності фахівця принципу наступності, спираємось на висновки щодо зв’ язку початкових економічних знань школярів та їхнього майбутнього професійного вибору, визначеного М. Вачевським, В. Мадзігоном, Н. Примаченко [3]. Підтримуючи таку авторську думку, вважаємо доцільним залучати студентів до проведення зі школярами профорієнтаційних заходів (бесід, івент-заходів, екскурсій тощо), підготовка до яких сприятиме не лише актуалізації професійно-комунікативних умінь студентів, але й даватиме їм можливість відчути причетність до професійної спільноти, що в результаті впливатиме на мотивацію професійної реалізації.

Аналізуючи науково-методичні підходи до формування економіста, який би відповідав вимогам галузевих стандартів та вимогам працедавців, Р. Кубанов пропонує переглянути підходи до організації навчального процесу в економічному закладі освіти. Так, виокремлюючи чотири блоки дисциплін (гуманітарний, природничо-науковий, загально-економічний та професійний), автор пропонує виділити три рівні взаємодії дисциплін навчального плану підготовки економістів-бакалаврів: перший рівень має здійснити взаємодію між дисциплінами гуманітарного (природничо-наукового) блоків та економічними дисциплінами. Другий рівень виявляє взаємодію економічних дисциплін та дисциплін загально математичного напряму, що мають озброїти майбутнього економіста сучасними технологіями керування в галузі економіки (математичного аналізу, перспективного моделювання тощо). Третій рівень, за думкою науковця, відображає взаємодію між власне економічними дисциплінами, основною дисципліною при цьому визначено курс економічної теорії, знання $з$ якого мають стати засадничими для всіх інших професійно спрямованих дисциплін [7]. 


\section{СТАТИСТИЧНАОБРОБКА ТААНАЛІЗ РЕЗУЛЬТАТІВ ЕКСПЕРИМЕНТАЛЬНОӤ РОБОТИЗФОРМУВАННЯ КОНКУРЕНТОСПРОМОЖНОСТІМАЙБУТНЬОГОФАХІВЦЯМУНІЦИПАЛЬНОӤЕКОНОМІКИ}

Дослідження О. Романовською організаційнопедагогічних умов підготовки конкурентоздатного фахівця в інженерно-педагогічних навчальних закладах, сфокусувало ¥ї мислення щодо поєднання у межах одного компоненту мотивації та структури знань майбутніх інженерів-педагогів, що виявилось у визначенні мотиваційнокогнітивного компоненту зазначеного утворення. Зміст цього компоненту, за думкою автора, передбачає професійно спрямовану орієнтацію і мотивацію навчально-професійної діяльності, мотивацію досягнення, високий рівень домагань, потребу в саморозвитку й оволодінні професією, а також систему професійних знань [11]. В дослідженні також спирались на комплекс методик, апробованих рядом дослідників, що дозволяють діагностуватирівень конкурентоспроможності майбугніх фахівців $[1 ; 5 ; 6 ; 8 ; 11]$.

Виклад основного матеріалу. 3 метою перевірки гіпотези щодо ефективності формування конкурентоспроможності майбутнього фахівця муніципальної економіки за допомогою запропонованої науково-методичної системи було проведено експеримент, у якому брали участь студенти 1-x - 4 курсів факультету Економіки та підприємництва Харківського національного університету міського господарства імені О.М. Бекетова, Для визначення сформованості конкурентоспроможності майбутніх фахівців муніципальної економіки необхідно було виявити кількісні та якісні зміни компонентів зазначеного утворення студентів експериментальних та контрольних груп через дослідження визначених критеріїв, а саме мотивація професійного навчання, мотивація на успіх/невдачу, потреба у досягненнях, сформованість фахових компетенцій, сформованість іншомовної компетентності, здатність до адаптації, здатність до творчості, самостійність, вміння йти на ризик, комунікабельність та рефлексивність.

Динаміка зрушень у сформованості кожного iз критеріїв конкурентоспроможності відстежувалась і вимірялась за допомогою моніторингового інструментарію на основі методик, апробованих попередніми дослідниками для формування конкурентоспроможності майбутніх фахівців інших галузей, а також авторські ідеї щодо формування конкурентоспроможності майбутніх фахівців муніципальної економіки. В якості методів математичної статистики використовувалися критерії Стюдента та Фішера.

Слід зазначити, що експеримент проходив у природних умовах, не порушуючи логіки та ходу навчального процесу. У ході експерименту встановлювалися правомірність, дієвість та ефективність наукової системи формування конкурентоспроможності студентів у процесі навчально-професійної діяльності.

Контрольний зріз сформованості конкурентоспроможності майбутніх економістів, що був проведений у кінці експерименту, засвідчив суттєві позитивні зрушення за всіма критеріями, що показано у таблиці 1.

Таблиця 1.

Результати сформованості конкурентоспроможності майбутнього фахівця муніципальної економіки (\%)

\begin{tabular}{|c|c|c|c|c|c|c|}
\hline \multirow[t]{2}{*}{ Рівні } & \multicolumn{3}{|c|}{ ЕГ (126 осіб) } & \multicolumn{3}{|c|}{ КГ (134 особи) } \\
\hline & До експ. & $\begin{array}{l}\text { Після } \\
\text { експ. }\end{array}$ & Приріст & До експ. & $\begin{array}{l}\text { Після } \\
\text { ексn. }\end{array}$ & $\begin{array}{l}\text { Пpu- } \\
\text { picm }\end{array}$ \\
\hline \multicolumn{7}{|c|}{ Мотиваційний критерій } \\
\hline \multicolumn{7}{|c|}{ Мотивачія професійного навчання } \\
\hline - високий & 9,5 & 24,6 & $+15,1$ & 10,4 & 13,4 & $+3,0$ \\
\hline - середній & 28,6 & 54,0 & $+25,4$ & 29,1 & 34,3 & $+5,2$ \\
\hline - низький & 61,9 & 21,4 & $-40,5$ & 60,5 & 52,3 & $-8,2$ \\
\hline \multicolumn{7}{|c|}{ Мотивачія на успіх/невдачу } \\
\hline $\begin{array}{l}\text { - яскраво виражена мотивація } \\
\text { на успіх }\end{array}$ & 11,9 & 29,4 & $+17,5$ & 11,2 & 21,6 & $+10,4$ \\
\hline $\begin{array}{l}\text { - середні показ-ники } \\
\text { мотивації на успіх (надія) }\end{array}$ & 36,5 & 56,3 & $+19,8$ & 38,1 & 47,0 & $+8,9$ \\
\hline - мотивація на невдачу & 51,6 & 14,3 & $-37,3$ & 50,7 & 31,4 & $-19,3$ \\
\hline
\end{tabular}




\section{СТАТИСТИЧНАОБРОБКА ТААНАЛІЗ РЕЗУЛЬТАТІВ ЕКСПЕРИМЕНТАЛЬНОӤ РОБОТИЗФОРМУВАННЯ КОНКУРЕНТОСПРОМОЖНОСТІМАЙБУТНЬОГОФАХІВЦЯМУНШИИАЛЬНОӤ ЕКОНОМІКИ}

\begin{tabular}{|c|c|c|c|c|c|c|}
\hline - високий & 11,1 & 31,7 & $+20,6$ & 11,9 & 17,9 & $+6,0$ \\
\hline - середній & 38,1 & 53,2 & $+15,1$ & 36,6 & 42,5 & $+5,9$ \\
\hline - низький & 50,8 & 15,1 & $-35,7$ & 51,5 & 39,6 & $-11,9$ \\
\hline \multicolumn{7}{|c|}{ Когнітивно-діяльнісний критерій } \\
\hline \multicolumn{7}{|c|}{ Сформованість фахових компетенцій } \\
\hline - високий & 6,4 & 37,3 & $+\mathbf{3 0 , 9}$ & 5,2 & 12,7 & $+7,5$ \\
\hline - середній & 25,4 & 51,6 & $+26,2$ & 28,4 & 51,5 & $+23,1$ \\
\hline - низький & 68,2 & 11,1 & $-57,1$ & 66,4 & 36,6 & $-30,6$ \\
\hline \multicolumn{7}{|c|}{ Сформованість іниомовної компетентності } \\
\hline - високий & 10,3 & 21,4 & $+11,1$ & 11,9 & 17,2 & $+5,3$ \\
\hline - середній & 32,6 & 49,2 & $+16,6$ & 35,1 & 46,3 & $+11,2$ \\
\hline - низький & 57,1 & 29,4 & $-27,7$ & 53,0 & 36,5 & $-16,5$ \\
\hline \multicolumn{7}{|c|}{ Здатність до адаптаиії } \\
\hline - висока & 8,7 & 22,2 & $+13,5$ & 7,5 & 11,9 & $+4,4$ \\
\hline - задовільна & 46,0 & 62,7 & $+16,7$ & 47,0 & 53,7 & $+6,7$ \\
\hline - низька & 45,3 & 15,1 & $-30,2$ & 45,5 & 34,4 & $-11,1$ \\
\hline \multicolumn{7}{|c|}{ Особистісний критерій } \\
\hline \multicolumn{7}{|c|}{ Здатність до творчості } \\
\hline - високий & 11,9 & 23,0 & $+11,1$ & 14,2 & 17,2 & $+3,0$ \\
\hline - середній & 50,8 & 61,1 & $+10,3$ & 51,5 & 58,9 & $+7,4$ \\
\hline - низький & 37,3 & 15,9 & $-21,4$ & 34,3 & 23,9 & $-10,4$ \\
\hline \multicolumn{7}{|c|}{ Самостійність } \\
\hline - високий & 6,3 & 26,2 & $+19,9$ & 7,5 & 15,8 & $+8,3$ \\
\hline - середній & 42,9 & 58,7 & $+15,8$ & 41,8 & 52,2 & $+10,4$ \\
\hline - низький & 50,8 & 15,1 & $-35,7$ & 50,7 & 32,0 & $-18,7$ \\
\hline \multicolumn{7}{|c|}{ Вміння йти на ризик } \\
\hline - висока & 7,1 & 23,0 & $+15,9$ & 8,2 & 13,4 & $+5,2$ \\
\hline - задовільна & 21,4 & 54,0 & $+32,6$ & 22,4 & 33,6 & $+11,2$ \\
\hline - низька & 71,5 & 23,0 & $-48,5$ & 69,4 & 53,0 & $-16,4$ \\
\hline \multicolumn{7}{|c|}{ Комунікабельність } \\
\hline - адекватна & 14,3 & 25,4 & $+11,1$ & 15,7 & 17,9 & $+2,3$ \\
\hline $\begin{array}{l}\text { - неадекватно- } \\
\text { екстравертована }\end{array}$ & 44,4 & 53,2 & $+8,8$ & 46,3 & 50,7 & $+4,4$ \\
\hline - неадекватно-інтровертована & 41,3 & 21,4 & $-19,9$ & 38,0 & 31,3 & $-6,7$ \\
\hline \multicolumn{7}{|c|}{ Рефлексивний критерій } \\
\hline \multicolumn{7}{|c|}{ Рефлексивність } \\
\hline - високий & 15,1 & 27,8 & $+12,7$ & 17,2 & 20,9 & $+3,7$ \\
\hline - середній & 50,8 & 64,3 & $+13,5$ & 47,8 & 53,0 & $+5,2$ \\
\hline - низький & 34,1 & 7,9 & $-26,2$ & 35,0 & 26,1 & $-10,7$ \\
\hline
\end{tabular}




\section{СТАТИСТИЧНАОБРОБКА ТААНАЛЗ РЕЗУЛЬТАТІВ ЕКСПЕРИМЕНТАЛЬНОӤ РОБОТИЗ ФОРМУВАННЯ КОНКУРЕНТОСПРОМОЖНОСТІМАЙБУТНЬОГОФАХІВЦЯМУНШИПАЛЬНОЇ ЕКОНОМІКИ}

Узагальнення отриманих даних дозволило також визначити кількість студентів на початку та наприкінці експериментальної роботи, сформованість конкурентоспроможності яких відповідала одномуз визначених рівнів: високому, середньому чи низькому. При розподілі студентів за рівнями (високий, середній, низький) керувались тим, що студенти, які знаходяться на високомурівні, виявили у процесі дослідження від $75 \%$ високих показників за всіма критеріями і до $25 \%$ середніх показників; до середнього рівня віднесли тих студентів, які виявили до $25 \%$ високих показників, 50-75\% середніх та 25\% низьких показників; до низького рівня віднесли тих студентів, які виявили до 75\% низьких показників, навіть, якщо уних було до 25\% високих показників, або близько 50\% середніх та 50\% низьких показників. Таким чином, отримали дані розподілу студентів за рівнями сформованості конкурентоспроможності майбутнього фахівця муніципальної економіки на початку експерименту, які узагальнили у таблиці 2 та на рис. 1.

3 метою підтвердження достовірності отриманих результатів експерименту використовувалися методи математичної статистики. Для визначення статистичної значущості різниці у змінах рівнів сформованості конкурентоспроможності майбутнього фахівця муніципальної економіки використовували статистичний аналіз узагальнених даних таблиці 13 використанням описових статистик середнього арифметичного $\bar{X}$, вибіркової дисперсії $\sigma^{2} \quad$ та середньоквадратичного відхилення $\sigma$ рівнів сформованості конкурентоспроможності майбутніх фахівців муніципальної економіки. Для визначення цих статистик використовуємо такі формули:

$\bar{x}=\frac{1}{n} \sum_{i=1}^{k} x_{i} n_{i}, \sigma^{2}=\frac{1}{n} \sum_{i=1}^{k}\left(x_{i}-\bar{x}\right)^{2} n_{i}$

Таблиця 2.

Сформованість конкурентоспроможності майбутнього фахівця муніципальної економіки

\begin{tabular}{|c|c|c|c|c|}
\hline $\begin{array}{c}\text { Рівні/зміст } \\
\text { виявлення }\end{array}$ & $\begin{array}{c}\text { ЕГ до } \\
\text { експерименту,\% }\end{array}$ & $\begin{array}{c}\text { ЕГ після } \\
\text { експерименту,\% }\end{array}$ & $\begin{array}{c}\text { КГ до } \\
\text { експерименту,\% }\end{array}$ & $\begin{array}{c}\text { КГ після } \\
\text { експерименту,\% }\end{array}$ \\
\hline
\end{tabular}

Стійка мотивація до професійного навчання, яскраво виражена мотивація до успіху у діяльності, високий рівень потреби у досягненнях; сформованість фахових компетенцій та іншомовної компетенції на високому рівні, висока здатність до адаптації у процесі діяльності; прагнення виявляти творчість у професії, самостійність у судженнях та у діяльності, здатність до обгрунтованого ризику у професійній діяльності, відповідальність за його наслідки, високий рівень адекватності у комунікації; високий рівень рефлективності у професійній реалізації.

\begin{tabular}{|c|c|c|c|}
\hline високий & $\mathbf{1 0 , 3 2 ( 1 3 )}$ & $11,19(15)$ & $16,42(22)$ \\
Середній рівень &
\end{tabular}

Середній рівень мотивації до професійного навчання, середні показники мотивації до успіху (успіх розглядається як надія та сподівання) у діяльності, середній рівень потреби у досягненнях (обумовленість зовнішніми чинниками); переважна сформованість фахових компетенцій та іншомовної компетенції, здатність до адаптації у процесі діяльності; залежність творчих процесів у професії від зовнішнього стимулювання, самостійність у судженнях та у діяльності, прагматичний підхід до ризику у професійній діяльності, здатність до адекватності у комунікації; середній рівень рефлективності у професійній реалізації.

\begin{tabular}{|c|c|c|c|c|}
\hline середній & $\mathbf{3 8 , 1 0 ( 4 8 )}$ & $\mathbf{5 6 , 3 5}(71)$ & $\mathbf{3 8 , 8 1}(52)$ & $\mathbf{4 7 , 7 6 ( 6 4 )}$ \\
\hline \multicolumn{3}{|c|}{ Низький рівень } \\
\hline
\end{tabular}

Низька мотивація до професійного навчання, виявлення переважно мотивації на уникнення невдач у діяльності, несформованість потреби у досягненнях; низький рівень сформованості фахових компетенцій та не сформованість іншомовної компетенції, низька здатність до адаптації у процесі діяльності; відсутність прагнення виявляти творчість у професії, несамостійність у судженнях та у діяльності, нездатність до ризику у професійній діяльності або виявлення невиправдано ризикованої поведінки, неадекватно-екстровертована або інтровертована комунікативна поведінка; низький рівень рефлективності у професійній реалізації.

низький $51,59(65)$ $16,67(21)$ $50,00(67)$ $35,82(48)$ 


\section{СТАТИСТИЧНАОБРОБКА ТААНАЛЗ РЕЗУЛЬТАТІВ ЕКСПЕРИМЕНТАЛЬНОӤ РОБОТИЗФОРМУВАННЯ КОНКУРЕНТОСПРОМОЖНОСТІМАЙБУТНЬОГОФАХІВЦЯМУНПЦИПАЛЬНОӤ ЕКОНОМІКИ}

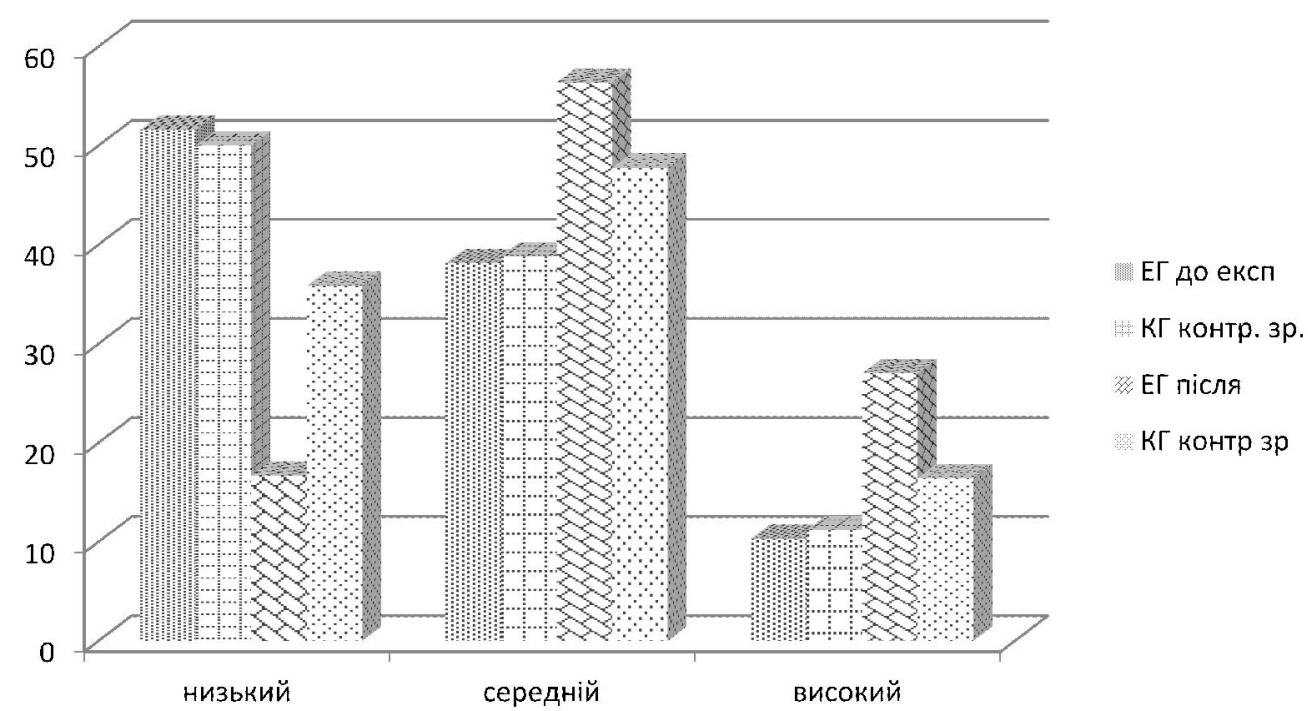

Рис. 1 Порівняльні гістограми змін сформованості конкурентоспроможності майбутнього фахівця муніципальної економіки студентів ЕГ та КГ

Тут $x_{i}$ - це рівні показників (низькому рівню відповідає значення $x_{1}=0$, середньому рівню - значення $x_{2}=1$ та високому рівню-значення $\left.x_{3}=2\right), k$-число рівнів відповідного показника, $n_{i}$ - кількість студентів відповідного рівня, $n$ дорівнює 126 та 134 відповідно для ЕГ і КГ.

Крім того, обчислимо відповідні вибірков коефіцієнти варіації $\mathrm{V}$ для кожного показника за формулою:

$$
V=\frac{\sigma}{\bar{x}} \text {. }
$$

Результати обробки даних у ЕГ на початку та після впровадження експериментальної роботи щодо сформованості конкурентоспроможності майбутнього фахівця муніципальної економіки, а у КГ (констатувальний та контрольний зрізи) наведено в таблиці 3.

Проаналізуємо результати, відтворені у табл. 3 . Після впровадження наукової системи формування конкурентоспроможності майбутнього фахівця муніципальної економіки позиції у ЕГ за всіма показниками трьох компонентів середнє арифметичне стало більше, а у КГ не суттєво змінилося (тобто, в експериментальній групі, на відміну від контрольної, відсоток студентів 3 високими рівнями показників збільшився). Одержаний результат вказує на ефективність експериментально апробованої наукової системи.

Можливі відхилення значень показників від середніх рівнів характеризуються вибірковим середньоквадратичним відхиленням (1), що не суттєво змінилося для всіх показників трьох компонентів. Але це абсолютний показник розсіювання. Відносним показником розсіювання значень показників навколо середнього $\epsilon$ вибірковий коефіцієнт варіації (2). Відповідно до результатів, представлених у табл. 1 - 3, визначаємо, що в експериментальній групі після застосування наукової системи формування конкурентоспроможності майбутніх фахівців муніципальної економіки розсіювання навколо середнього для всіх показників усіх компонентів стало менше, а у контрольній групі за цей час розсіювання не суттєво змінилося.

За даними табл. 4 та формулою (2) обчислимо коефіцієнти варіації для експериментальних та контрольних груп. Для групи ЕГ до експерименту маємо наступний коефіцієнт варіації

$$
V \approx \frac{0,670}{0,587} \approx 1,141
$$

відповідно після експерименту

$$
V \approx \frac{0,653}{1,103} \approx 0,592
$$

Бачимо, що дані після експерименту менш розсіяні, тобто результати дослідження мають більшу стабільність.

Для групи КГ у констатувальному зрізі маємо коефіцієнт варіації 


\section{СТАТИСТИЧНАОБРОБКА ТААНАЛЗЗ РЕЗУЛЬТАТІВ ЕКСПЕРИМЕНТАЛЬНОӤ РОБОТИЗФОРМУВАННЯ КОНКУРЕНТОСПРОМОЖНОСТІМАЙБУТНЬОГОФАХІВЦЯМУНШИПАЛЬНОӤЕКОНОМІКИ}

Результати статистичної обробки даних динаміки сформованості конкурентоспроможності майбутніх фахівців муніципальної економіки

\begin{tabular}{|c|c|c|c|c|c|c|c|c|c|}
\hline \multirow[t]{2}{*}{ Показники } & \multirow[t]{2}{*}{$\begin{array}{c}\text { Гру } \\
- \\
\text { па }\end{array}$} & \multicolumn{2}{|c|}{$\begin{array}{c}\text { Середнє } \\
\text { арифметичне, } \bar{x}\end{array}$} & \multicolumn{2}{|c|}{ Дисперсія, $\sigma^{2}$} & \multicolumn{2}{|c|}{$\begin{array}{c}\text { Середньо } \\
\text { квадратичне } \\
\text { відхилення, } \sigma\end{array}$} & \multicolumn{2}{|c|}{$\begin{array}{l}\text { Коефіцієнт } \\
\text { варіації, V }\end{array}$} \\
\hline & & $\begin{array}{c}\text { конст. } \\
\text { зріз }\end{array}$ & $\begin{array}{c}\text { контр. } \\
\text { зріз }\end{array}$ & $\begin{array}{c}\text { конст. } \\
\text { зріз }\end{array}$ & $\begin{array}{c}\text { контр. } \\
\text { зріз }\end{array}$ & $\begin{array}{c}\text { конст. } \\
\text { зріз }\end{array}$ & $\begin{array}{c}\text { контр. } \\
\text { зріз }\end{array}$ & $\begin{array}{c}\text { конст } \\
\text { зріз }\end{array}$ & $\begin{array}{c}\text { контр } \\
\text { зріз }\end{array}$ \\
\hline \multirow{2}{*}{$\begin{array}{c}\text { Мотивація } \\
\text { професійного } \\
\text { навчання }\end{array}$} & $\mathrm{E} \Gamma$ & 0,476 & 1,032 & 0,440 & 0,459 & 0,663 & 0,677 & 1,393 & 0,656 \\
\hline & КГ & 0,500 & 0,612 & 0,459 & 0,506 & 0,677 & 0,711 & 1,354 & 1,162 \\
\hline \multirow{2}{*}{$\begin{array}{l}\text { Мотивація на } \\
\text { успіх/невдачу }\end{array}$} & $\mathrm{E} \Gamma$ & 0,603 & 1,151 & 0,477 & 0,414 & 0,691 & 0,643 & 1,146 & 0,559 \\
\hline & КГ & 0,604 & 0,903 & 0,463 & 0,520 & 0,680 & 0,721 & 1,126 & 0,798 \\
\hline \multirow{2}{*}{$\begin{array}{c}\text { Потреба у } \\
\text { досягненях }\end{array}$} & $\mathrm{E} \Gamma$ & 0,603 & 1,167 & 0,441 & 0,440 & 0,664 & 0,663 & 1,101 & 0,568 \\
\hline & КГ & 0,604 & 0,784 & 0,456 & 0,528 & 0,675 & 0,727 & 1,117 & 0,927 \\
\hline \multirow{2}{*}{$\begin{array}{c}\text { Сформованість } \\
\text { фахових } \\
\text { компетенцій }\end{array}$} & $\mathrm{E} \Gamma$ & 0,381 & 1,262 & 0,363 & 0,416 & 0,602 & 0,645 & 1,580 & 0,511 \\
\hline & КГ & 0,388 & 0,769 & 0,342 & 0,418 & 0,585 & 0,647 & 1,508 & 0,841 \\
\hline \multirow{2}{*}{$\begin{array}{l}\text { Сформованість } \\
\text { іншомовної } \\
\text { компетентності }\end{array}$} & $\mathrm{E} \Gamma$ & 0,532 & 0,921 & 0,455 & 0,502 & 0,675 & 0,709 & 1,269 & 0,770 \\
\hline & КГ & 0,589 & 0,806 & 0,481 & 0,499 & 0,694 & 0,707 & 1,178 & 0,877 \\
\hline \multirow{2}{*}{$\begin{array}{c}\text { Здатність до } \\
\text { адаптації }\end{array}$} & $\mathrm{E} \Gamma$ & 0,635 & 1,071 & 0,406 & 0,368 & 0,637 & 0,607 & 1,003 & 0,567 \\
\hline & КГ & 0,619 & 0,776 & 0,385 & 0,413 & 0,620 & 0,643 & 1,002 & 0,829 \\
\hline \multirow{2}{*}{$\begin{array}{c}\text { Здатність до } \\
\text { творчості }\end{array}$} & $\mathrm{E} \Gamma$ & 0,746 & 1,071 & 0,428 & 0,384 & 0,654 & 0,620 & 0,877 & 0,579 \\
\hline & КГ & 0,799 & 0,925 & 0,444 & 0,412 & 0,666 & 0,642 & 0,834 & 0,694 \\
\hline \multirow[t]{2}{*}{ Самостійність } & $\mathrm{E} \Gamma$ & 0,556 & 1,103 & 0,374 & 0,410 & 0,616 & 0,640 & 1,108 & 0,580 \\
\hline & КГ & 0,567 & 0,836 & 0,395 & 0,451 & 0,628 & 0,672 & 1,107 & 0,804 \\
\hline \multirow{2}{*}{$\begin{array}{c}\text { Вміння йти на } \\
\text { ризик }\end{array}$} & $\mathrm{E} \Gamma$ & 0,357 & 1,001 & 0,372 & 0,460 & 0,610 & 0,678 & 1,709 & 0,677 \\
\hline & КГ & 0,388 & 0,604 & 0,402 & 0,508 & 0,634 & 0,713 & 1,634 & 1,180 \\
\hline \multirow{2}{*}{$\begin{array}{c}\text { Комунікабель- } \\
\text { ність }\end{array}$} & $\mathrm{E} \Gamma$ & 0,730 & 1,040 & 0,483 & 0,467 & 0,695 & 0,683 & 0,952 & 0,657 \\
\hline & КГ & 0,776 & 0,866 & 0,487 & 0,475 & 0,698 & 0,689 & 0,899 & 0,796 \\
\hline \multirow[t]{2}{*}{ Рефлексивність } & $\mathrm{E} \Gamma$ & 0,809 & 1,198 & 0,456 & 0,315 & 0,675 & 0,561 & 0,834 & 0,468 \\
\hline & КГ & 0,821 & 0,948 & 0,429 & 0,467 & 0,655 & 0,683 & 0,798 & 0,720 \\
\hline
\end{tabular}

$$
V \approx \frac{0,679}{0,612} \approx 1,110
$$

відповідно у контрольному зрізі маємо

$$
V \approx \frac{0,696}{0,806} \approx 0,864
$$

Бачимо, що коефіцієнти варіації для даних у констатувальному зрізі та у контрольному зрізі для КГ незначно відрізняються.

Таким чином, визначаємо, що одержані результати для експериментальної групи є більш стабільні.

Наступним кроком статистичного аналізу була

Таблиця 3. 


\section{СТАТИСТИЧНАОБРОБКА ТААНАЛІЗ РЕЗУЛЬТАТІВ ЕКСПЕРИМЕНТАЛЬНОӤ РОБОТИЗФОРМУВАННЯ КОНКУРЕНТОСПРОМОЖНОСТІМАЙБУТНЬОГОФАХІВЦЯМУНШИПАЛЬНОӤЕКОНОМІКИ}

Тут, як і раніше, $x_{i}$ - це рівні показників, $k-$ число рівнів відповідного показника, - кількість студентів відповідного рівня, $n$, дорівнює 126 та 134 відповідно для ЕГ і КГ.

Перевіримо нульові гіпотези про нульове значення коефіцієнту асиметрії та відповідно про нормальний розподіл даних у експериментальних та контрольних групах. Для перевірки використовуємо коефіцієнти асиметрії.

Обчислимо коефіцієнти асиметрії для експериментальних та контрольних груп. Для групи ЕГ до експерименту маємо наступний вибірковий коефіцієнт асиметрії

$$
A \approx \frac{89,399}{126} \approx 0,709 ;
$$

відповідно після експерименту

$$
A \approx-\frac{12,819}{126} \approx-0,102 \text {. }
$$

Для групи КГ при констатувальному зрізі маємо коефіцієнт асиметрії

$$
A \approx \frac{88,781}{134} \approx 0,662,
$$

відповідно при контрольному зрізі маємо

$$
A \approx \frac{37,868}{134} \approx 0,283 .
$$

Порівнявши вибіркові коефіцієнти асиметрії 3 критичними значеннями для гіпотези про нормальність розподілу, робимо висновок: коефіцієнт асиметрії для експериментальних груп та контрольних груп несуттєво відрізняється від нуля. Це вказує на нормальний розподіл рівнів серед студентів груп. Таким чином, ми можемо використовувати t-критерій Стьюдента.

Сформулюємо нульову та альтернативну гіпотези для експериментальної та контрольної груп. Отже, нульова гіпотеза $H_{\circ}$ полягає у наступному: різниця середніх показників двох сукупностей об'єктів - експериментальної (контрольної) групи до і після застосування методик несуттєва для $k=\mathrm{N}_{1}+\mathrm{N}_{2}-2$ ступенів свободи, тобто високий рівень сформованності конкурентоспроможності майбутніх фахівців муніципальної економіки уекспериментальній групі пояснюється випадковими чинниками.

Альтернативна гіпотеза $H_{1}$ полягає у наступному: різниця середніх показників двох сукупностей об'єктів - експериментальної (контрольної) групи до і після застосування системи методик суттєва для $k=\mathrm{N}_{1}+\mathrm{N}_{2}-2$ ступенів свободи, тобто саме запровадження обгрунтованої системи пояснює високий рівень сформованості професійної мобільності майбутніх фахівців муніципальної економіки у експериментальній групі.

Емпіричне значення t-критерію Стьюдента визначається за формулою:

$$
t=\frac{\overline{x_{2}}-\overline{x_{1}}}{\sqrt{\frac{\sigma_{1}^{2}}{N_{1}}+\frac{\sigma_{2}^{2}}{N_{2}}}}
$$

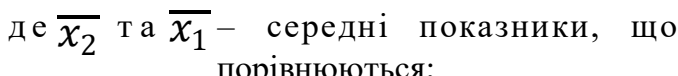
порівнюються;

$\mathrm{N}_{1}, \mathrm{~N}_{2}-$ кількість студентів у групі (експериментальної або контрольної) до і після експерименту (у нашому випадку $\mathrm{N}_{1}=\mathrm{N}_{2}$ );

$$
\sigma_{1}^{2}, \sigma_{2}^{2} \begin{gathered}
- \text { значення дисперсії ознаки, що } \\
\text { аналізується. }
\end{gathered}
$$

У таблиці значень критичних точок розподілу $\mathrm{t}$-критерію ступеням свободи $\mathrm{k}_{1}=126+126-2=250$ (у випадку ЕГ) та $\mathrm{k}_{2}=134+134-2=266$ (у випадку КГ) відповідає випадок “нескінченності” у рядках таблиці. При рівні значущості $\mathrm{p}=0,98$ відповідне табличне значення критерію Стьюдента $\epsilon$ $t_{t a b}=2,36$. Знайдемо фактичні значення критерію Стьюдента за даними таблиці 4 та формулою (3). Для експериментальної групи ЕГ маємо:

$$
t_{\text {fact }}^{\mathrm{E} \Gamma} \approx \frac{1,103-0,587}{\sqrt{\frac{0,449+0,426}{126}}} \approx 6,192 .
$$

Для контрольної групи КГ маємо:

$$
t_{f a c t}^{\mathrm{K} \Gamma} \approx \frac{0,806-0,612}{\sqrt{\frac{0,461+0,485}{134}}} \approx 2,309 .
$$

Таким чином, фактичні значення різниці середніх для експериментальної групи більше табличного критичного, а отже, можна зробити висновок, що різниця між середніми величинами рівнів сформованості конкурентоспроможності майбутнього фахівця муніципальної економіки в експериментальній групі $\epsilon$ статистично значущою, а різниці між двома сукупностями (контингентом експериментальної групи до і після впровадження методик) суттєві та не випадкові. Цей факт $є$ підставою до відхилення нульової гіпотези та прийняття альтернативної для експериментальної групи.

Навпаки, фактичне значення різниці середніх 


\section{СТАТИСТИЧНАОБРОБКА ТААНАЛІЗ РЕЗУЛЬТАТІВ ЕКСПЕРИМЕНТАЛЬНОӤ РОБОТИЗФОРМУВАННЯ КОНКУРЕНТОСПРОМОЖНОСТІМАЙБУТНЬОГОФАХІВЦЯМУНШИПАЛЬНОӤЕКОНОМІКИ}

для контрольної групи нижче табличного критичного, а, й отже, можна зробити висновок, що різниці між середніми величинами рівнів сформованості конкурентоспроможності майбутнього фахівця муніципальної економіки контрольної групи є статистично незначущими та пояснюються випадковими чинниками. Цей факт $\epsilon$ підставою для прийняття нульової гіпотези для контрольної групи.

Проведене дослідження щодо впровадження представленої наукової системи у процес професійної підготовки майбутніх фахівців муніципальної економіки дозволило позитивно вплинуги наформування вних конкурентоспроможності. Так, іiі сформованість на високому рівні визначено у $26,98 \%$; на середньому рівні - у 56,35 \% студентів ЕГ, тоді як у студентів контрольної групи було визначено високий та середній рівні сформованості конкурентоспроможності відповідно 16,42 \% та 47,76\%.

Ці результати є статистично значущими відповідно представлених обчислень за методами математичної статистики.

Отже, висунута на початку дослідження гіпотеза щодо позитивного впливу теоретично обгрунтованих та реалізованих у навчальновиховномупроцесі профільного ВЗО педагогічних умов на рівень сформованості конкурентоспроможності майбутнього фахівця муніципальної економіки знайшла своє підтвердження.

Для підтвердження значущості статистичних висновків застосуємо критерій Фішера. За цим критерієм перевірка значної різниці між розподілом рівнів в експериментальній та контрольній групах здійснюється для кожного рівня узагальнених даних окремо. Таким чином, для кожного рівня експериментальної та контрольної груп висувається нульова гіпотеза $H_{\text {: }}$ частка відповідного рівня у двох сукупностях об'єктів - експериментальної (або контрольної) групи до і після застосування методик несуттєво змінилася. Альтернативна гіпотеза $H_{1}$ - полягає у тому, що зміни часток суттєві.

Для застосування критерію Фішера перекладемо відсоткові частки рівнів узагальнених даних табл. 3 у величини центрального кута, який вимірюється в радіанах, за формулою:

$$
\varphi_{i}=2 \arcsin \left(\sqrt{m_{i}}\right),
$$

де $m_{i}=\frac{n_{i}}{100}-\underset{\text { рівня для експериментальної (або }}{\text { відові частки відповідного }}$ контрольної) групи до і після застосування методик, що виражена у частках одиниці.

Відповідно емпіричне значення критерію одержуємо за формулою:

$$
\varphi_{i}^{*}=\left(\varphi_{i}^{1}-\varphi_{i}^{2}\right) \sqrt{\frac{N_{1} \cdot N_{2}}{N_{1}+N_{2}}}
$$

де $\varphi_{i}^{1}-$ кут, щовідповідає більшій відсотковій частці $m_{i} ; \varphi_{i}^{2}-\quad$ кут, що відповідає меншій відсотковій частці $m_{i} ; N_{1}$ - кількість спостережень у першої вибірці; $N_{2}$ - кількість спостережень у другій вибірці.

Визначимо табличне значення критерію Фішера при рівні статистичної значущості 0,95: $\varphi_{\text {кр }}^{*}=2,31$. За узагальненими даними табл. критерію, результати узагальнили у табл. 5 .

Таким чином, для високого, середньогота низького рівнів експериментальних груп одержусмо, що вимірне значення критерію Фішера більше критичного табличного, тобто конкурентоспроможність майбугнього фахівця муніципальної економіки після експерименту в групі ЕГ статистично значущо позитивно змінилася (доля високого та середнього рівнів статистично значущо збільшилася, а доля низького рівня статистично значущо зменшилася). 3 іншого боку, для високого, середнього танизького рівнів контрольної групи одержуємо, що вимірне значення критерію Фішера менше критичного табличного, тобто конкурентоспроможність майбутнього фахівця муніципальної економіки після експерименту в контрольній групі КГ статистично несуттєво змінилася.

Висновок. Проведене дослідження щодо впровадження представленої науково-методичної

Статистичні характеристики динаміки сформованості конкурентоспроможності

Таблиця 4.

\begin{tabular}{|c|c|c|c|c|c|c|}
\hline \multirow[t]{2}{*}{$\begin{array}{l}\text { Гру } \\
\text { па }\end{array}$} & \multicolumn{2}{|c|}{$\begin{array}{c}\text { Середнє } \\
\text { арифметичне, } \bar{x}\end{array}$} & \multicolumn{2}{|c|}{ Дисперсія, $\sigma^{2}$} & \multicolumn{2}{|c|}{$\begin{array}{c}\text { Середньоквадратичне } \\
\text { відхилення, } \sigma\end{array}$} \\
\hline & конст. зріз & контр. зріз & конст. зріз & контр. зріз & конст. зріз & контр. зріз \\
\hline $\mathrm{E} \Gamma$ & 0,587 & 1,103 & 0,449 & 0,426 & 0,670 & 0,653 \\
\hline КГ & 0,612 & 0,806 & 0,461 & 0,485 & 0,679 & 0,696 \\
\hline
\end{tabular}
майбутніх фахівців муніципальної економіки 
Таблиця 5.

Результати статистичної значущості експерименту за критерієм Фішера

\begin{tabular}{|c|c|c|c|c|c|c|}
\hline Рівні & $\begin{array}{c}\text { Частка } \\
\text { при } \\
\text { конст. } \\
\text { зрізі, } \\
\%\end{array}$ & $\begin{array}{c}\text { Частка } \\
\text { при } \\
\text { контр. } \\
\text { зрізі, } \\
\text { \% }\end{array}$ & $\begin{array}{c}\varphi_{i}^{1} \\
\text { (для } \\
\text { більшої } \\
\text { частки) }\end{array}$ & $\begin{array}{c}\varphi_{i}^{2} \\
\text { (для } \\
\text { меншої } \\
\text { частки) }\end{array}$ & $\varphi_{i}^{*}=\left(\varphi_{i}^{1}-\varphi_{i}^{2}\right) \sqrt{\frac{N_{1} \cdot N_{2}}{N_{1}+N_{2}}}$ & $\begin{array}{c}\text { Співвідно- } \\
\text { шення }\end{array}$ \\
\hline $\begin{array}{l}\text { ЕГ } \\
\text { високий } \\
\text { рівень }\end{array}$ & 10,32 & 26,98 & 1,092 & 0,654 & 3,478 & \\
\hline $\begin{array}{l}\text { КГ } \\
\text { високий } \\
\text { рівень }\end{array}$ & 11,19 & 16,42 & 0,834 & 0,684 & 1,191 & \\
\hline $\begin{array}{l}\text { ЕГ } \\
\text { середній } \\
\text { рівень }\end{array}$ & 38,10 & 56,35 & 1,696 & 1,342 & 2,809 & \\
\hline $\begin{array}{l}\text { КГ } \\
\text { середній } \\
\text { рівень }\end{array}$ & 38,81 & 47,76 & 1,526 & 1,346 & 1,429 & \\
\hline $\begin{array}{l}\text { ЕГ } \\
\text { низький } \\
\text { рівень }\end{array}$ & 51,59 & 16,67 & 1,602 & 0,841 & 6,043 & \\
\hline $\begin{array}{l}\text { КГ } \\
\text { низький } \\
\text { рівень }\end{array}$ & 50,00 & 35,82 & 1,570 & 1,283 & 2,276 & \\
\hline
\end{tabular}

системи формування конкурентоспроможності у процес професійної підготовки майбутніх фахівців муніципальної економіки дозволило позитивно вплинути на формування в них конкурентоспроможності. Одержані результати засвідчили динаміку змін за всіма критеріями, що вказує на ефективність експериментально апробованої наукової системи.

\section{ЛІТЕРАТУРА}

1. Бодров В. А. Психология профессиональной пригодности: учебноепособиедля вузов/В.А.Бодров. - Москва: ПЕРСЭ, 2001. - 511 с.

2. Бикова В. О. Сутність, структура та діагностика рівня сформованості конкурентоздатності майбугнього фахівця: навч.-метод. посіб./В.О.Бикова. - Дніпропетровськ : Дніпропетр. ун-т ім. Альфреда Нобеля, 2012. - 88 с.

3. Вачевський М. В. Основи економіки: навч. посіб. / Мирон Вачевський, Василь Мадзігон, Наталія Примаченко. - Київ: Пед. думка, 2007. $612 \mathrm{c}$.

4. Завалевський Ю. І. Теоретико-методичні засади формування вчителя як конкурентоспроможного фахівця: монографія/Ю. І. Завалевський. - Чернівці: Букрек, 2014. - 416 c.

5. Занюк С. С. Психология мотивации: теория и практика мотивирования. Мотивационный тренинг / С. С. Занюк. - Киев: Эльга-Н; НикаЦентр, 2001. - 351 с.
6. Карпов А. В. Психология рефлексивных механизмовдеятельности/А.В.Карпов,В.В.Пономарева. - Москва: ИП РАН, 2004. - 422 с.

7. Кубанов Р. Вимоги до професійної підготовки фахівців економічних спеціальностей та їх реалізація в освітньому процесі вищого навчального закладу / Р. Кубанов // Науковий вісник Мелітопольського державного педагогічного університету. - 2014. - № 2 (13). C. 294-301.

8. Практикум по психологии менеджмента и профессиональной деятельности / под ред. Г. С. Никифорова, М. А. Дмитриевой, В. М. Снеткова. - Москва: Речь, 2003. - 448 с.

9. Резван О. О. Формування професійнорефлексивної позиції майбутнього фахівця автомобільно-дорожньої галузі: монографія / О. О. Резван. - Харків: Точка, 2014. - 400 с.

10. Романовський О. Г. Критерії та рівні розвитку конкурентоспроможності фахівця: навч.метод. посіб. / О. Г. Романовський, О. С. Пономарьов, С. М. Резнік. - Харків: НТУ “ХПІ", 2014. - 40 с.

11. Романовська О. О. Організаційнопедагогічні умови підготовки конкурентоздатного фахівця в інженерно-педагогічних навчальних закладах: автореф. дис. на здобуття наук. ступеня канд. пед. наук: спец. 13.00.04 “Теорія і методика професійної освіти” / О. О. Романовська. - Харків, 2011. - 22 c.

12. A taxonomy for learning, teaching, and 
assessing: a revision of Bloom's taxonomy of educational objectives / ed. Lorin W. Anderson, David Krathwohl. - NewYork: Longman, 2001. - 352 p.

\section{REFERENCES}

1. Bodrov, V. A. (2001). Psihologiya professionalnoj prigodnosti: uchebnoe posobie dlya vuzov [Psychology of professional suitability]. Moscow: PERSEH, 511 p. [in Russian].

2. Bykova, V. O. (2012). Sutnist, struktura ta diahnostyka rivnia sformovanosti konkurentozdatnosti maibutnoho fakhivtsia: navch.-metod. posib. [Essence, structure and diagnostics of the level of competitiveness formation of a future professional]. Dnipropetrovsk: Dnipropetr. un-t im. Alfreda Nobelia, 88 p. [in Ukrainian].

3. Vachevskyi, M. V., Madzihon, V. M. \& Prymachenko, N. M. (2007). Osnovy ekonomiky: navch. posib. [Fundamentals of economics]. Kyiv: Ped. dumka, 612 p. [in Ukrainian].

4. Zavalevskyi, Yu. I. (2014). Teoretykometodychni zasady formuvannia vchytelia yak konkurentospromozhnoho fakhivtsia: monohrafiia [Theoretical and methodical approaches for formation of a teacher as a competitive professional]. Chernivtsi: Bukrek, 416 p. [in Ukrainian].

5. Zanyuk, S. S. (2001). Psikhologiya motivatsii: teoriya i praktika motivirovaniya. Motivatsionnyy trening [Psyhology of motivation: theory and practice of motivation. Motivational training]. Kiev: Elga-N; Nika-Tsentr, 351 p. [in Russian].

6. Karpov, A. V. \& Ponomareva, V. V. (2004). Psihologiya refleksivnyh mekhanizmov deyatelnosti [Psychology of reflexive mechanisms of activity]. Moscow: IP RAN, 422 p. [in Russian].

7. Kubanov, R. (2014). Vymohy do profesiinoi pidhotovky fakhivtsiv ekonomichnykh spetsialnostei ta yikh realizatsiia $\mathrm{v}$ osvitnomu protsesi vyshchoho navchalnoho zakladu [Requirements for professional training of professionals of economic specialities and their realization in the educational process of the higher educational establishment]. Scientific herald of Melitopol State Pedagogical University, no. 2 (13), pp. 294-301. [in Ukrainian].

8. Nikiforova, G. S., Dmitrieva, M.A. \& Snetkova, V. M. (Ed.). (2003). Praktikum po psihologii menedzhmenta i professionalnoj deyatelnosti [Practical training in psychology of management and professional activities]. Moscow: Rech, 448 p. [in Russian].

9. Rezvan, O. O. (2014). Formuvannia profesiino-refleksyvnoi pozytsii maibutnoho fakhivtsia avtomobilno-dorozhnoi haluzi: monohrafiia. [Formation of professional and reflexive position of a future professional of automobile and road economy]. Kharkiv: Tochka, 400 p. [in Ukrainian].

10. Romanovskyi, O. H., Ponomarov, O. S. \& Reznik, S. M. (2014). Kryterii ta rivni rozvytku konkurentospromozhnosti fakhivtsia: navch.metod. posib. [Criteria and levels for development of competitiveness a professional]. Kharkiv: NTU "KhPI", 40 p. [in Ukrainian].

11. Romanovska, O. O. (2011). Orhanizatsiinopedahohichni umovy pidhotovky konkurentozdatnoho fakhivtsia $\mathrm{v}$ inzhenerno-pedahohichnykh navchalnykh zakladakh [Organizational and pedagogical conditions for training of a competitive professional in engineering and pedagogical educational establishments]. Extended abstract of candidate's thesis. Kharkiv, 22 p. [in Ukrainian].

11. Lorin, W., Anderson \& Krathwohl, D. (Ed.). (2001). A taxonomy for learning, teaching, and assessing: a revision of Blooms taxonomy of educational objectives. NewYork: Longman, 352 p. [in English].

Стаття надійшла до редакції 04.09.2018

\section{G580} nочатку".

"Лравильно про речі розмірковує той, хто простежує іхній розвиток від самого (1)

Аврелій Августин християнсъкий теолог і иерковний діяч

“Бути річкою, у якій зливаються гаряче серие й холодний розум, не допускати поспішних, непродуманих рішень - це одна з вічних віток педагогічної майстерності. Зів'яне вона - усі книжні завдання перетворяться в прах".

Василь Сухомлинський украйнський педагог, публіиист

\section{G58080}

